\title{
Lead Metal Adsorption from its Solution using Seagrass Biomass Enhalus Acoroides
}

\author{
*Siti Masita, Irwan Said \& Suherman \\ Pendidikan Kimia/FKIP - Universitas Tadulako, Palu - Indonesia 94119 \\ Received 12 June 2020, Revised 10 July 2020, Accepted 07 August 2020 \\ doi: 10.22487/j24775185.2020.v9.i3.pp158-161
}

\begin{abstract}
Seagrass is one of the macrophyta plants containing enough biomass. Recently, seagrass has been used for filtering waste, drugs and sources of chemicals. Seagrass also functions to stabilize the soft bases where most species grow, especially with solid root systems and cross each other. Therefore, seagrass has the potential to absorb heavy metal ions from the solution. This research aimed to determine the optimum weight and optimum contact time for $\mathrm{Pb}$ metal adsorption. Weight variation of seagrass biomass was 60, 90, and $120 \mathrm{mg}$ while variation in contact time was 60, 90, and 120 minutes. The results obtained optimum weight of seagrass biomass to absorb $\mathrm{Pb}$ metal was $60 \mathrm{mg}$ with $98.42 \% \mathrm{~Pb}$ absorbed, and optimum contact time for seagrass biomass to absorb $\mathrm{Pb}$ metal was 60 minutes with $95.45 \% \mathrm{~Pb}$ absorbed.
\end{abstract}

Keywords: Adsorption, $\mathrm{Pb}$ metal, biomass, seagrass enhalus acoroides

\section{Pendahuluan}

Perkembangan industri yang makin pesat menyebabkan semakin banyak bahan buangan yang bersifat racun di buang ke lingkungan. Bahan-bahan buangan ini yang nantinya menjadi limbah dan mencemari lingkungan dalam jumlah yang sulit di kontrol secara tepat. Di Indonesia, sumber pencemar dapat berasal dari limbah rumah tangga, perusahaan pertambangan, industri dan lain-lain. Bahan- bahan yang beracun ini akan berakibat buruk bagi makhluk hidup yang hidup disekitar lingkungan yang tercemar (Purnomo \& Muchyiddin, 2007; Murdhiani dkk., 2011; Ika dkk., 2012; Tangio, 2013).

Salah satu bahan pencemar yang sangat berbahaya apabila mencemari perairan yaitu logam berat. Logam berat berbahaya karena dapat mengganggu kehidupan organisme di lingkungan jika keberadaannya melampaui ambang batas (Suhud dkk., 2012). Logam timbal (Pb) merupakan logam berat beracun yang secara alami terdapat pada batuan dan lapisan kerak bumi (Anjani \& Koestiari, 2014; Damayanti dkk., 2012). Logam berat ini sangat berbahaya karena apabila berada diperairan, akan berdampak buruk bagi kelangsungan hidup hewan maupun mikroorganisme yang hidup didalamnya. Selain itu logam timbal juga dapat menyebabkan keracunan pada manusia. Keracunan yang terjadi bisa bersifat kronik dan akut. Gejala yang timbul berupa mual, muntah, sakit perut hebat, kelainan fungsi otak, anemia berat, kerusakan ginjal, bahkan kematian dapat terjadi dalam waktu 1 -2 hari (Widyaningrum dkk., 2007).
Alternatif bahan biologis yang dapat digunakan sebagai bahan baku biosorben adalah limbah produk pertanian. Limbah produk pertanian ini umumnya sangat mudah didapat dan murah. Penggunaan limbah pertanian sebagai adsorben juga mampu mengurangi banyaknya limbah pertanian sehingga memberdayakan suatu produk limbah pertanian yang memiliki nilai jual. Saat ini telah dikembangkan metode adsorpsi dengan menggunakan biomassa tumbuhan yang dikenal dengan fitofiltrasi. Dasar pemikiran dari fitofiltrasi adalah dengan mengunakan biomassa tumbuhan yang telah mati sebagai pengikat ion logam (Alayubi, 2007; Wahjuni \& Kostradiyanti, 2008).

Beberapa logam berat dapat terakumulasi oleh beberapa tumbuhan Macrophyta, Potamogeton lucens, Salviniaherzogoi, Eichhornia crassipes, Myriophyllumbrasillensis, Cabomba sp., Myriophyllum spicatum. Selain itu, tumbuhan Macrophyta yang lain, Ceratophyllum demersum, dapat digunakan sebagai biosorben untuk ion logam $\mathrm{Pb}(\mathrm{II}), \mathrm{Cu}(\mathrm{II})$ dan $\mathrm{Zn}(\mathrm{II})$. Lamun merupakan salah satu dari tumbuhan macrophyta, tumbuhan yang mempunyai akar (rhizome dan serabut akar), batang, daun, bunga dan beberapa spesies berbuah. Oleh karena itu, lamun berpotensi untuk menghilangkan ion-ion logam berat dari larutannya.

Tulisan ini dimaksudkan untuk mengurai adsorpsi logam timbal menggunakan biomassa lamun yang berasal dari Desa Tingkulang, Tomini, Parigi Moutong.

*Correspondence:

Siti Masita

e-mail: sitimasita005@gmail.com

(c) 2020 the Author(s) retain the copyright of this article. This article is published under the terms of the Creative Commons Attribution License 4.0, which permits unrestricted non-commercial use, distribution, and reproduction in any medium, provided the original work is properly cited. 


\section{Metode}

Alat yang digunakan dalam penelitian ini adalah gelas kimia, gelas erlenmeyer, labu ukur, spatula, corong, batang pengaduk,shaker, $\mathrm{pH}$ meter, ayakan, aluminium foil, blender, oven, kertas saring dan SSA. Bahan yang digunakan dalam penelitian ini adalah sampel lamun Enhalus acoroides asal dari Desa Tingkulang, larutan $\mathrm{NaOH} 0.1 \mathrm{~N}, \mathrm{HNO}_{3} 0.1 \mathrm{~N}$, padatan $\mathrm{Pb}\left(\mathrm{NO}_{3}\right)_{2}$, larutan induk $\mathrm{Pb} 1000 \mathrm{ppm}$, larutan induk $\mathrm{Pb} 60$ ppm.

\section{Pengambilan Sampel}

Sampel yang digunakan dalam penelitian ini adalah lamun Enhalus acoroides yang diperoleh dari Desa Tingkulang, Kecamatan Tomini, Kabupaten Parigi Moutong, Provinsi Sulawesi Tengah.

\section{Preparasi Sampel}

Lamun dibersihkan dengan air bersih kemudian dipotong kecil-kecil dan dikeringkan di bawah sinar matahari, kemudian dikeringkan lagi menggunakan oven dengan suhu $100^{\circ} \mathrm{C}$ selama 6 jam untuk mengurangi kadar air dan mendiamkannya pada suhu kamar. Lamun tersebut dihaluskan menggunakan blender, kemudian di ayak sehingga diperoleh serbuk yang lebih halus. Biomassa ditimbang menggunakan neraca digital dan disimpan dalam wadah tertutup.

\section{Pembuatan Larutan Induk Pb 1000 ppm dalam $\mathrm{Pb}\left(\mathrm{NO}_{3}\right)_{2}$}

0.8 gram dimasukkan ke dalam gelas kimia setelah itu ditambahkan dengan $5 \mathrm{~mL}$, aquadest kemudian diaduk sampai serbuk tersebut larut seluruhnya. Larutan tersebut dimasukkan ke dalam labu ukur $1000 \mathrm{~mL}$, kemudian ditambahkan aquadest sampai tanda batas.

\section{Pembuatan Larutan Induk Pb 100 ppm}

Larutan induk $\mathrm{Pb} 1000$ ppm diambil 25 $\mathrm{mL}$, kemudian dimasukkan ke dalam labu ukur 250 $\mathrm{mL}$ dan ditambahkan aquadest sampai tanda batas dan dikocok sampai homogen.

\section{Penentuan Variasi Berat terhadap Adsorpsi Logam Pb}

Serbuk lamun yang terbentuk dari langkah sebelumnya diambil sebanyak 60.90 dan $120 \mathrm{mg}$. Dicampurkan dengan $25 \mathrm{~mL}$ larutan $\mathrm{Pb} 60 \mathrm{ppm}$ dan ditambahkan larutan buffer dengan $\mathrm{pH} 4$ pada masing-masing erlenmeyer. Gelas erlenmeyer ditutup dengan kertas aluminium foil yang diikat dengan karet dan di kocok dengan shaker selama 55 menit, kemudian mendiamkannya selama 5 menit. Filtrat dan residu dipisahkan dengan menggunakan kertas saring dan mengukur adsorbansi larutan $\mathrm{Pb}$ menggunakan spektrofotometer serapan atom.

\section{Penentuan Waktu Optimum terhadap Adsorpsi Logam Pb}

Adsorben dengan berat 1 gram dimasukkan ke dalam $20 \mathrm{~mL}$ larutan $\mathrm{Pb}(\mathrm{II}) 100 \mathrm{ppm}$ dengan menambahkan 10 tetes larutan $\mathrm{NaOH} 0.1 \mathrm{~N}$ dan ditambahkan 1 tetes larutan $\mathrm{HNO}_{3} 0.1 \mathrm{~N}$ sebagai bahan pengawet agar tidak terjadi perubahan- perubahan pada komposisi larutan. Kemudian memasukkan ke dalam gelas erlenmeyer $250 \mathrm{~mL}$. Masing-masing gelas erlenmeyer ditutup dengan kertas aluminium foil dan dikocok menggunakan shaker dengan variasi waktu 60.90 dan 120 menit. Filtrat dan residu di pisahkan menggunakan kertas saring dan di ukur adsorbansi larutan menggunakan spektrofotometer serapan atom.

\section{Hasil dan Pembahasan}

\section{Pengolahan Sampel Sebagai Adsorben}

Penelitian ini merupakan salah satu alternatif untuk menghilangkan logam berat pada larutan dengan menggunakan bahan-bahan biologis sebagai adsorben. Saat ini telah dikembangkan metode adsorpsi dengan menggunakan biomassa tumbuhan yang dikenal dengan fitofiltrasi. Dasar pemikiran dari fitofiltrasi adalah dengan menggunakan biomassa tumbuhan yang telah mati sebagai pengikat ion logam (Al-ayubi, 2007). Adapun berat serbuk lamun yang diperoleh ialah 35.5 gram.

\section{Variasi Berat terhadap Adsorpsi Logam Timbal oleh Biomassa Lamun Enhalus Acoroides}

Variasi berat serbuk lamun digunakan untuk penentuan berat optimum biomassa lamun sebagai adsorben logam timbal. Penentuan berat optimum pada adsorpsi logam timbal menggunakan biomassa lamun, dimana biomassa lamun yang dipakai ialah biomassa lamun Enhalus acoroides dabn dilakukan pada 3 variasi berat serbuk biomassa lamun yaitu 60, 90 dan $120 \mathrm{mg}$.

Tabel 1. Hasil pengukuran konsentrasi $\mathrm{Pb}$ yang teradsorpsi pada variasi berat pada biomassa lamun Enhalus acoroides

\begin{tabular}{cc}
\hline Berat $(\mathrm{mg})$ & \% Pb terserap \\
\hline 60 & 98.42 \\
90 & 97.87 \\
120 & 92.36 \\
\hline
\end{tabular}

Penurunan penyerapan logam $\mathrm{Pb}$ dari $60 \mathrm{mg}$ sampai $120 \mathrm{mg}$ sehingga menyebabkan turunnya presentase logam timbal yang terserap. Serapan logam timbal relatif menurun, hal ini terjadi karena permukaan adsorben sudah dalam keadaan jenuh dengan ionion logam timbal, dimana pusat aktif telah jenuh dengan ion logam maka peningkatan adsorben relatif tidak meningkatkan penyerapan ion logam oleh adsorben (Tumin dkk., 2008; Ghazy dkk., 2009; Radyawati, 2011). Berdasarkan uraian diatas maka belum dipastikan serapan optimum untuk adsorpsi logam timbal menggunakan biomassa Lamun.

Berdasarkan Tabel 1 maka diketahui berat optimum serbuk biomassa Lamun terhadap adsorpsi logam timbal yaitu sebesar $60 \mathrm{mg}$ berat logam timbal yang terserap yaitu $0.67 \mathrm{mg} / \mathrm{g}$, dan persentase logam timbal yang terserap yaitu $98.42 \%$. Gaya yang mengikat adsorbat oleh adsorben, adsorpsi fisik adalah gaya Van der Walls. Akibat adanya gaya-gaya yang bekerja antara adsorbat dan 
adsorben menyebabkan proses adsorpsi logam dapat terjadi, dimana proses adsorpsi ini relatif berlangsung sangat cepat dan reversibel. Adsorbat yang terikat secara lemah pada permukaan adsorben, dapat bergerak dari suatu bagian permukaan kebagian permukaan lain. Adsorpsi fisik terjadi dimana $\mathrm{Pb}(\mathrm{II})$ terperangkap kedalam rongga atau pori-pori dari adsorben.

Proses adsorpsi logam timbal dari larutan sampel dengan adsorben serbuk biomassa Lamun, selain berlangsung secara fisik, proses adsorpsi juga berlangsung secara kimia. Adsorpsi kimia terjadi karena adanya reaksi kimia antara molekul-molekul adsorbat dengan permukaan adsorben yang berupa pembentukan senyawa kompleks. Pembentukan senyawa kompleks, atom atau ion logam disebut sebagai atom pusat, sedangkan atom yang mendonorkan elektronnya ke atom pusat disebut atom donor atau ligan. Atom donor terdapat pada suatu ion atau molekul netral yang memiliki atomatom donor yang dikoordinasikan pada atom pusat. Suatu molekul dikatakan sebagai ligan jika atommnya memiliki pasangan elektron bebas atau memiliki elektron tak berpasangan.

Selulosa merupakan senyawa organik yang terdapat pada dinding sel bersama lignin yang berperan dalam mengokohkan struktur tumbuhan. Dilihat dari strukturnya, selulosa dan lignin mempunyai potensi yang cukup besar untuk dijadikan sebagai penyerap karena gugus - $\mathrm{OH}$ yang terikat dapat berinteraski dengan komponen adsorbat. Adanya gugus $-\mathrm{OH}$ pada selulosa dan lignin lebih kuat menyerap zat yang bersifat polar polar daripada zat yang kurang polar. Adanya gugusgugus polar ini diduga dapat berinteraksi dengan logam berat sehingga serbuk lamun mempunyai reaktifitas kimia yang tinggi dan menyebabkan sifat polielektrolit kation sehingga dapat berperan sebagai adsorben tethadap logam berat terhadap air yang tercemar (Poedjiadi, 2007).

Tabel 2. Hasil pengukuran konsentrasi Pb yang teradsorpsi pada variasi waktu kontak optimum pada biomassa Lamun Enhalus acoroides

\begin{tabular}{cc}
\hline Waktu kontak (menit) & $\% \mathrm{~Pb}$ terserap \\
\hline 60 & 95.45 \\
90 & 88.63 \\
120 & 94.69 \\
\hline
\end{tabular}

Hasil penelitian untuk pengaruh waktu kontak dari larutan ion logam timbal terhadap kemampuan adsorpsi biomassa Lamun Enhalus acoroides seperti yang terihat pada Tabel 2 yang memperlihatkan bahwa adsorpsi $\mathrm{Pb}$ dipengaruhi oleh waktu kontak antara larutan dan sampel biomassa Lamun Enhalus acoroides. Waktu kontak antara ion logam dengan adsorben sangat mempengaruhi daya serap. Semakin lama waktu kontak maka serapan juga akan meningkat sampai pada waktu tertentu akan mencapai maksimum dan setelah itu akan turun kembali. Pada penelitian ini waktu kontak optimum di peroleh pada menit ke 60 dengan penyerapan mencapai $95.45 \%$. Hal ini disebabkan karena semua sisi aktif yang terdapat pada biomassa Lamun Enhalus acoroides saling berikatan dengan ion-ion timbal maka dengan memperbesar konsentrasi ion timbal jumlah zat yang terserap akan meningkat secara linear. Selanjutnya jika sisi aktif telah jenuh dengan ion logam maka peningkatan konsentrasi ion logam relatif tidak meningkatkan penyerapan ion logam oleh biomassa (Radyawati, 2011). Efisiensi penyerapan menurun setelah menit ke 60, karena terjadi proses desorpsi. Hal ini merupakan fenomena dalam adsorpsi fisika yang menyatakan bahwa proses adsorpsi bersifat reversibel. Hal ini karena ikatan lemah yang terjadi antara adsorben dengan ion logam akan lepas kembali ke dalam larutannya karena semakin lama waktu kontak (Lestari, 2010).

Pada waktu ke-90 menit terjadi penurunan penyerapan dengan persentase penyerapan sebesar $88.63 \%$. Hal ini di duga karena kurangnya adsorbat yang terserap pada adsorben. Selain itu, hsl ini dikarenakan ketidakefisiennya proses penyerapan yang tidak aktif pada biomassa Lamun dengan larutannya, kemudian pada waktu 120 menit terjai kenaikan penyerapan yang tidak terlalu signifikan dimana presentase penyerapannya yaitu 94.69\%. Waktu kontak antara ion logam dengan adsorben sangat dipengaruhi daya serap. Semakin lama waktu kontak maka penyerapan juga akan meningkat sampai padan waktu tertentu akan mencapai maksimum dan setelah itu akan turun dan kemudian akan meningkat kembali.

Persentasi penyerapan ion $\mathrm{Pb}$ oleh biomassa Lamun Enhalus acoroides pada masing-masing variasi waktu adalah 60 menit sebesar $95.45 \%$, 90 menit sebesar $88.63 \%$, dan pada 120 menit sebesar 94.69 $\%$. Hasil perhitungan tersebut menunjukkan bahwa waktu kontak paling optimum yang diperoleh adalah pada waktu ke-60 menit sebesar 95.45\%. Waktu kontak tersebut merupakan waktu kontak optimum, dimana terjadi penurunan kadar Timbal dalam sampel telah mencapai titik maksimalnya, maka akan digunakan untuk keperluan variabel penelitian selanjutnya, agar data yang diperoleh menggambarkan efektifitas serapan yang optimum.

\section{Kesimpulan}

Berat optimum yang diperlukan serbuk biomassa Lamun Enhalus acoroides untuk menyerap logam timbal adalah sebesar $60 \mathrm{mg}$ dan persentase logam timbal yang terserap yaitu $98.42 \%$. Waktu kontak optimum yang diperlukan biomassa Lamun Enhalus acoroides untuk menyerap ion logam timbal adalah 60 menit, dan persentase ion timbal yang terserap yaitu $95.45 \%$.

\section{Ucapan Terima Kasih}

Penulis mengucapkan terima kasih kepada laboran Laboratorium Pendidikan Kimia FKIP UNTAD yang telah membantu selama proses 
penelitian di Laboratorium Kesehatan Kota Palu terimakasih atas bantuan kepada penulis selama penelitian.

\section{Referensi}

Al-ayubi, M. C., Barroroh, H., \& Dewi, D. C. (2015). Studi keseimbangan adsorpsi merkuri(II) pada biomassa daun enceng gondok (eichhornia crassipes). Alchemy: Jounral of Chemistry, 1(2), 8391.

Anjani, R. P., \& Koestiari, T. (2014). Penetuan massa dan waktu kontak optimum adsorpsi karbon granual sebagai adsorben logam berat $\mathrm{Pb}(\mathrm{II})$ dengan pesaing ion $\mathrm{Na}^{+}$. Unesa Journal of Chemistry, 3(3), 159-163.

Damayanti, Rahman, N., \& Supriadi. (2012). Adsorpsi timbal $(\mathrm{Pb})$ dan zink $(\mathrm{Zn})$ dari larutannya menggunakan arang hayati (biocharcoal) kulit pisang kepok berdasarkan variasi pH. Jurnal Akademika Kimia, 1(4), 159_ 165.

Ghazy, S. E., \& El-Morsy, S. (2009). Adsorption of lead from aqueous solution by modified activated carbon prepared from olive stones. African Journal of Biotechnology, 8(17), 4140-4148.

Ika, Tahril, \& Said, I. (2012). Analisis logam timbal (Pb) dan besi (Fe) dalam air laut di wilayah pesisir pelabuhan ferry Taipa Kecamatan Palu Utara. Jurnal Akademika Kimia, 1(4), 181-186.

Lestari, S. (2010). Pengaruh berat dan waktu kontak untuk adsorpsi timbal(II) oleh adsorben dari kulit batang jambu biji (psidium guajava 1.). Jurnal Kimia Mulawarman, 8(1), 2008-2011.

Murdhiani. (2011). Penurunan logam berat timbal (Pb) pada kolam biofiltrasi air irigasi dengan menggunakan tanaman air (aquatic plant) pendahuluan bahan dan metode. Jurnal Ilmu Pertanian Kultivar, 5(2), 1-8.

Poedjiadi, A. (2007). Dasar-dasar biokimia. Jakarta: UI Press.

Purnomo, T., \& Muchyiddin. (2007). Analisis kandungan timbal $(\mathrm{Pb})$ pada ikan bandeng (chanos chanos forsk) di tambak Kecamatan Gresik. Neptunus: Majalab Ilmiab Kelautan, 14(1), 68-77.

Radyawati. 2011. Pembuatan biocharcoal dari kulitpisang kepok untuk penyerapan logam timbal (Pb) dan logam seng (Zn). Palu: UNTAD-Press.

Suhud, I., Tiwow, V. M. A., \& Hamzah, B. (2012). Adsorpsi ion kadmium(II) dari larutannya menggunakan biomassa akar dan batang kangkung air (ipomoea aquatica forks). Jurnal Akademika Kimia, 1(4), 153-158.

Tangio, J. S. (2013). Adsorpsi logam timbal (Pb) dengan menggunakan biomassa enceng gondok (eichhorniacrassipes). Jurnal Entropi, 8(1), 500506.

Tumin, N. D., \& Chuah, A. L. (2008). Adsorption of copper from aqueous solution by elais guineensis kernel activated carbon. Journal of Engineering Science and Technology, 3(2), 180-189.

Wahjuni, S., \& Kostradiyanti, B. (2008). Penurunan angka peroksida minyak kelapa tradisional dengan adsorben arang sekam padi ir 64 yang diaktifkan dengan kalium hidroksida. Jurnal Kimia, 2(1), 57-60.

Widyaningrum, Miskiyah, \& Suismono. (2007). Bahaya kontaminasi logam berat dalam sayuran dan alternatif pencegahan cemarannya. Buletin Teknologi Pascapanen Pertanian, 3(1), 17-27. 